\title{
The Influence of Relationship Quality on Electronic Word of Mouth for Mobile Review Site Users in Saudi Arabia Market
}

\author{
Fathia Mohammed Issa \\ Faculty of Economics and Administration, King Abdulaziz University, Jeddah, Kingdom of Saudi Arabia \\ Email: fathiaessa24@gmail.com
}

How to cite this paper: Issa, F. M. (2021). The Influence of Relationship Quality on Electronic Word of Mouth for Mobile Review Site Users in Saudi Arabia Market. $i B u-$ siness, 13, 155-178. https://doi.org/10.4236/ib.2021.134010

Received: July 23, 2021

Accepted: November 1, 2021

Published: November 4, 2021

Copyright (๑) 2021 by author(s) and Scientific Research Publishing Inc. This work is licensed under the Creative Commons Attribution International License (CC BY 4.0).

http://creativecommons.org/licenses/by/4.0/

\section{(c) (i) Open Access}

\begin{abstract}
The main objective of this study is to identify how the relationship quality between consumers and mobile phone companies can influence electronic word of mouth. Accordingly, to achieve this research objective, the quantitative approach was adopted, and the needed information was collected by constructing a survey questionnaire method addressed to the target participants. The quantitative study was conducted, allowing for the collection of evidences in the customer provider relationship on client satisfaction, trust, and commitment as connected to electronic word of mouth. A total of 401 respondents completed consumer questionnaires. The results confirmed that, the more positive electronic word of mouth present within the consumer relationship, the more likely other individuals were to acquire services with that organization. The level of positive electronic word of mouth was correlated to the level of commitment to the brand held by the consumers and the level of trust in the company held by the consumers. In addition to that, a significant positive relationship exists between customers' satisfaction and electronic word of mouth. In light of these identified results, additional researches are necessary in order to more thoroughly explore the consumer business dynamic.
\end{abstract}

\section{Keywords}

Electronic Word of Mouth, Mobile Phones, Consumers, Relationship Quality, Trust, Commitment, Satisfaction

\section{Introduction}

With the emergence of social commerce and electronic word-of-mouth, such as review websites, consumers can seek out and share information regarding their 
experiences and their perceptions of products or services. A consumer will convey a positive attitude through e-WOM communication if they perceive that the vendor meets their needs.

Relationship marketing involves understanding and managing rapport between the consumers and a seller Due to the increasing competition, organizations today compete to create long-term relationships with their customers by ensuring that their products and services can meet customers' needs. Building a quality relationship with consumers is essential for businesses, especially the ones that are actively selling products and services online. Relationship dimensions, namely satisfaction, trust and commitment are vital for business success.

A study by Sheth and Kim (2017) reported that much of online shopping involves an emotional component of the customer. Customers are seeking a long-term emotional connection, which goes beyond clicking the buy button. Relationship quality can be defined in many ways, such as the way that customers perceive the nature of a relationship between businesses and meeting their needs (Myhal, Kang, \& Murphy, 2008). Relationship quality may depend on many factors, including the expertise of the business and the needs of a client; these needs may be unique or they may be general. Regardless, the business that will preserve relationships through quality is the business that best understands the foundations and principles of relationship quality and its impact on marketing.

This paper examines how relationship quality (satisfaction, trust and commitment) influences through electronic word of mouth in the context of the customers of mobile review sites of businesses in the Saudi market.

Globalization has resulted in incredible opening of markets, with incredible potential for expansion, however, Globalization pushes businesses to deal with new competitive forces that demand the application of articulated marketing strategies for improving customer relations. The concept of word-of-mouth has been a powerful tool for spreading product information from customer to customer. The concept of word-of-mouth translates into the online world as platforms where customers can share data and thoughts among themselves and with the business, which is being discussed, including the wide spreading through social media communication channels. Electronic word-of-mouth, in combination with social commerce, has been used over the years to allow businesses to reach their customers and related networks and to influence buying patterns. This study aims to examine the effect of relationship quality on positive electronic word-of-mouth, with the intent of facilitating best practices for firms in the Saudi market. Therefore, the research problem is: how does the relationship quality influence positive electronic word of mouth?

The study is intended to enrich the scientific approach to the growth of business, products, services and innovation in Saudi Arabia per the vision of what the country can achieve by 2030 (Khan, 2016). By better understanding the nature of the relationship between modern communication technologies and the marketing concept of word-of-mouth in the context of customer relationships it is hoped that this research contributes to the development of frameworks that 
enhance the utilization of this capacity. As explained by Clow and Baack (2009), studies of the application of new technologies can help to refine the understanding of market dynamics, as well as to provide perspectives that enhance the transformation of traditional word-of-mouth techniques to modern ones that applied to current electronic platforms. Additionally, the research will illustrate the importance of electronic word-of-mouth, its applicability in modern settings, and its potential in creating positive, satisfactory, trust-building, and committed customer relations. Moreover, for best the author knowledge there was no prior study has been conducted on this topic in Saudi Arabia. In the current competitive business environment, maintainable and lucrative relationships with buyers/customers are highly accentuated by organizations and customer commitment programs are considered key activities (Dick \& Basu, 1994). For this reason, organizations are focusing on distinct management strategies to attract and retain customers (Khoshsima, Kiani, Safari, Amari, Shifte, \& Vaseei, 2013).

The concept of word of mouth has been a powerful tool at presenting information between customers; word of mouth can be used in the online platforms where customers can share data among themselves and with businesses through available communication channels. Electronic word of mouth combined with social commerce has been used over the years to allow businesses reach customers and their related networks to influence buying patterns, as well as collaborative decisions made by customers regarding particular products or services. Though different researches have been made, this study aims at exploring relationship quality and customer satisfaction, trust and commitment, as they related to positive electronic word of mouth.

\section{Literature Review}

The emergence of internet technologies has created the need for additional research on the topic of electronic word-of-mouth. Market researchers such as Purnasari and Yuliando (2015) have outlined the importance of using online communications to reach customers, as well as for adapting new ways of propagating information that can help to build good consumer relationships. This is why Web 2.0 technologies are preferred to host platforms as customers can receive, share, and review products before committing themselves to their sellers. This is an interesting area of research, since it helps to develop quality relationships that shape the nature of commitment, trust, and satisfaction of customers.

\subsection{Relationship Marketing}

Relationship marketing is a key component in the determination of competitiveness of global industries, small business, and large corporations. Bilgihan and Bujisic (2015) stated that if companies want to build better relationships, they had to look after the things they were doing to add value in their interactions with customers. Having websites that are easily used can help to create better re- 
lationships. According to (Johanesova \& Vanova, 2020), relationship marketing is a form of marketing that focuses on customer retention and satisfaction. Moreover, it specifically focuses on the value of long-term customer relationships. They further argued that, relationship marketing is an aspect of the customer relationship management (CRM) that focuses on customer loyalty and long-term customer engagement rather than on short-term goals such as customer acquisition and individual sales.

\subsection{Relationship Quality}

Relationship quality describes the strength of affiliation between customers and sellers that developed through personalized communication (Kang, Oh, \& Sivadas, 2013). According to Niraj et al., (2008), Zargari and Hazraty (2016), customers want to feel relaxed, happy, and excited when they make their online purchase. Because of this, businesses must have the capacity to create the required emotional to establish long-term loyalty and commitment towards the firm. By its very definition, relationship quality is the strength of interconnections of sellers and customers. It is the measure of how strong a relationship there is between the online retailer and their customers, which predicts continued buying preferences and patterns and the sustainability of the relationship. On the other hand, Guede, Curiel, and Antonovlca (2017), they defined relationship quality as a multi-dimensional construct formed by trust, satisfaction, and commitment and restricted by the customer's review. They added that, these dimensions essential for the process of identifying, establishing, developing and maintaining the relations with clients' customers.

The literature reviewed provides many definitions to relationship quality (Poomduang \& Kheokao, 2019) defined relationship quality to the brand as the overall evaluation of strength, which is the arise of feeling within the customers minds towards the brand by considering of the strength through the feeling level in the consumers' minds. While Farooqi (2014) reported that, Relationship quality involves trust, feeling of security, and satisfaction. It also involves understanding, validation and care, as well as involves a range of positive feelings and emotions that may consequently produce a significant impact on the relationship.

Increasing research in the field of marketing has indicated that relationship quality is composed of various dimensions, and coordination of those dimensions can result in satisfied and committed customers. Tsao and Hsieh (2012) noted that the essential dimensions included reliability, assurance, empathy, responsiveness, and satisfaction. These attributes were necessary for the development of high quality relationships whose outcomes are trust, commitment, and satisfaction among customers. As such, businesses need to work with the aim of creating sustainable emotional connections so that can establish long-term relations that extend beyond a single purchase (Forrester \& Maute, 2001).

Regardless of the rapidly growing literature on relationship quality, there is also an increase in ambiguity with respect to the determinants and the nature of 
relationships. There is still a dire need for critical clarification based on context dependence frameworks. This necessitates the development of relationships at various levels, such as structural, social, and economical levels.

It is true that relationship quality can affect how customers perceive businesses, and influence their probability of making another purchase. The relationship quality is important because it reduces the perceived uncertainties that are present as a channel to confirm the firm's integrity. Therefore, with better relationship quality, online businesses have a higher probability of engaging in future transactions (Purnasari \& Yuliando, 2015). In addition, it is important to realize that relationship quality is made of three sub-dimensions, namely; satisfaction, commitment, and trust.

The Relationship Quality (customer commitment, trust and satisfaction) assesses to creating positive electronic word of mouth that achieving competitive excellence to attract customers, encourage communication, and assess consumer expectations with an intention of creating quality relations relative to customer commitment through positive electronic word of mouth (Frischmann \& Gensler, 2011; Park \& Kim, 2014).

Increasing research in the field of marketing has indicated that relationship quality is composed of various dimensions, and coordination of those dimensions can result in satisfied and committed customers. Relationships are influenced by a variety of customer experiences, including their perception of the quality and availability of the product or service. The aim of a good relationship to customers requires ensuring that clients have a good reason to maintain that relationship, and to make repurchases, indicating elevated trust and satisfaction, Tsao and Hsieh (2012) noted that the essential dimensions included satisfaction, trust and commitment. These attributes were necessary for the development of high quality relationships whose outcomes are trust, commitment, and satisfaction among customers. As such, businesses need to work with the aim of creating sustainable emotional connections so that they can establish long-term relations that extend beyond a single purchase (Forrester \& Maute, 2001). Customer-perceived relationship quality has been explored in a business-to-customer (B2C) setting using an instrumental single case study design (Myhal et al., 2008). The research demonstrates that more than 208 components are critical to customers' relationship quality perceptions (Myhal et al., 2008). Customer relationships may be difficult to replicate; as such, the quality of relationships an organization builds, and the ability of an organization to use the customer's perspective in a business setting, is significant in terms of the contribution that relationships make to greater knowledge as a whole, and in terms of gaps in knowledge (Myhal et al., 2008). Based on the contexts in which excellent quality relations matter, the RQ (relationship quality) should inevitably replace the aspect of customer satisfaction and service quality as the primary source of greater performance levels (Palmatier, Dante, Grewal, \& Evans, 2006). Regardless of the rapidly growing literature on relationship quality, there is also an increase in 
ambiguity with respect to the determinants and the nature of relationships. There is still a dire need for critical clarification based on context dependence frameworks. This necessitates the development of relationships at various levels, such as structural, social, and economical levels. In this case, there are powerful social bonds between the clients' and the managers' relationships. The bond can therefore enhance the core services or products, as well as their impacts on consumer satisfaction, with a perceived stronger value that is stronger compared to the economic resources and the company representatives (Haytko, 2004). Certainly, the relationship managers frequently act as the sole or primary contact point for customers, thus posing a noteworthy influence regarding the level of quality service delivery (Crosby et al., 1990). The failure or success of any given relationship is dependent on the manner that relationship managers behave or act, and the level of strength of the social bonds acting between them and subsequent customers.

Despite this concept, there exists minimal research on the antecedents pertaining to people-centered inter-organizational relationship quality (Bolton et al, 2003). Bolton pinpointed his framework using a multi-method research study depicting the relationships between restaurants and their close corporate clients. This intensive research explored the nature, determinants, and dimensions of RQ within an organizational context. Even though some studies in this field were advocating for diverse RQ compositions, the primary dimensions that proved to be significant encompassed the variables of trust, commitment, and satisfaction. This is the reason the approach and the context of the study at hand has often resulted in the conceptualization of relationship quality as a mere high-order paradigm composed of trust and satisfaction as the two main dimensions (Bolton et al., 2003).

According to Crosby et al., (1990), trust sets the basis for the ability of relying on the salesperson in such a manner that the buyer's expectations are met. In this case, the level of assurance and satisfaction alleged by the buyer with regards the future performance of the salesperson is due to the consistent and satisfactory nature of the past performances (Crosby et al., 1990). These are some of the elements that are viewed as being equally significant RQ dimensions, coexisting without any form of unplanned relationships prevailing between them. It is therefore a factor that acts in accordance with several studies identified in the literature as setting a basis on for modeling the core concept of interest, which prevails (Parsons, 2002).

\subsection{Trust}

According, Miquel-Romero et al. (2014) building trust is a game of managing relationships. Developing good relationships will make it easy for the management to improve trust and vice versa. In addition to developing good relations, the business may want to new products and services, to show customers' needs. By doing so, the customers will slowly build trust and stick to the business. In 
addition to that, trust is a concept that plays an important role in social and economic interactions. On the other hand, Consumers nowadays participate their experiences across various online platforms and rating reviews, received from various sources. Thus, if positive reviews are to come through various consistent online platforms and sources, reviews like this have a more persuasive effect on customer responses for products and services (Shankara, et.al, 2020).

\subsection{Satisfaction}

According to (Rawson, et al., 2013) satisfaction in business is the feeling that makes customers happy and eager to come back to the business for more products and services. Miquel-Romero et al. (2014) said that satisfaction is mainly achieved through the delivery of unique and high-quality products and services that fully meet the needs of the customers. Increased customer experience and satisfaction will greatly improve the reputation of the business.

\subsection{Commitment}

This refers to the intention by consumers to maintain a long-term relationship with a product or firm due to pricing, quality of products, but also the attachment that forms from the positive relations to the firm and to consumers in their social network who provide a positive view of the product or the firm (Datta, Foubert, \& Van Heerde, 2015). According to (Hechanova \& Cementina-Olpoc, 2013), commitment is the driving force that guides the activities of a business. Commitment is a concept with a wide scope, with the most important aspect being the business relationship with the customers. Business' commitment to its customers can be seen by the continued improvement of products and services to meet their needs in unique ways.

\subsection{Electronic Word-of-Mouth}

Electronic Word of mouth is a form of marketing where customers, rather than business intentions, drive interest in a product or service. E-WOM is a relationship based, since it focuses on person-to-person contact as it happens on internet-based platforms (Zhu \& Zhang, 2010). With the advancement of technology and the emergence of the internet, the word-of-mouth practice that once occurred almost exclusively in person or on the telephone has evolved into the more rapid proliferation of e-WOM events. The e-WOM occurs online whereby consumers from around the world share their perceptions of the product and the experience of purchasing it, including interactive components and quantitative ratings and rankings (Zhu \& Zhang, 2010). According to Chu and Choi (2011), electronic word-of-mouth refers to any positive or negative information made by customers regarding a product or an organization in various online platforms. This sharing of information among consumers has had considerable impact on consumer purchasing behavior. Today, consumers are not a passive target of information, but active communicators who pursue information from 
other customers about a product while providing their opinion-in an essence, a customer-to-customer channel.

There are many researchers cited in, Bhat \& Bhat (2020), have investigated the role of social media and e-WOM in creating opportunities for the consumers to spread positive word of mouth in the form of product reviews which helps other customers in making their purchasing decisions, and develops trust among its consumers that result more favorable attitude from consumer towards the brand. In addition to that, researchers confirmed that, social media could provide a rich basis for $\mathrm{C} 2 \mathrm{C}$ information thus can have a great influence on consumption decision. Whereas they investigated that, e-WOM, have the power to develop destination trust among its consumers and develops visit intension among them. Therefore, they conclude that, electronic word of mouth has a significant impact on the satisfaction of consumers because it helps in creating distinctive brand image in the minds of consumers.

Other researchers such as (Katz et al., 2017; King et al., 2014) described EWOM as similar to the traditional offline WOM in that, it is an interactive communication process for exchanging experiences and information about products or service. While differing from offline WOM in that, it is based on internet. In addition to that, EWOM is generally defined as the act of meeting and sharing opinions with each other on the internet and exchanging the ratings for services, which provide usability, accessibility, and persistence for information that serve unavailable in traditional offline WOM.

\subsection{Evolution of Word-of-Mouth (WOM) to Electronic Word-of-Mouth (e-WOM)}

The exchange of information between consumers has a considerable impact on the consumer's behavior, and it is effective in comparison to traditional marketing techniques. Electronic word-of-mouth (e-WOM) plays a crucial role in consumer spending decisions in that they will use the information shared to decide either to buy a product/service or not.

With the advancement of technology and the emergence of the internet, wordof-mouth has evolved into electronic word-of-mouth. The electronic word-ofmouth occurs online whereby consumers from distinct parts of the world share and interact regarding various products and services. Today, consumers are not a passive target of information; instead, they are active communicators who pursue information from other customers about a product, while providing their own opinion.

Electronic word-of-mouth is different from word-of-mouth in many ways. According to (Andreassen \& Streukens, 2009) traditional word-of-mouth encompasses spoken, one-on-one communication while electronic word-of-mouth is not one-on-one, but a passive reading of the message, and active writing of messages through a computer. Additionally, WOM is erasable due to a lack of proper recording, while e-WOM is not perishable since people interact online through various platforms such as social networks and blogs, and the message can be 
stored and retrieved in the future (Chu \& Choi, 2011). Interestingly, e-WOM does not involve one-on-one communication of the type that takes place online, such as email, instant message and Skype, since through e-WOM; the information is delivered to a group of people through the platform, and not an individual.

Furthermore, (Kannan \& Li, 2017), stated that, Consumers progress along the E-WOM communication process, moving from the E-WOM creation, to exposure, to evaluation stages, acting at times as senders and at other times receivers of E-WOM and shifting between these stages and roles in a non-linear way. Therefore, E-WOM plays a significant role in Consumer adoption behavior for technology-related products and service, E-WOM is positive for deciding whether or not to adopt relevant technology.

Such as, they consider credibility and quality as positive eWOM when they decide whether or not to adopt a new technology (Shankara et al., 2020).

\subsection{Link between Relationship Quality and e-WOM}

In addition to discussing relationship quality and e-WOM independently, there is a need to examine their own relationship in creating sustained customer commitment and loyalty. The link between relationship quality and e-WOM helps to define the personalized strategy through customer segmentation. Businesses need to establish priorities and values of their customers, hence the need for a communication channel where customers can read, review and share personal experiences. With information collected from electronic word-of-mouth, online businesses have been able to conduct analysis and informed reflection which helps to create a more sustainable customer relationship due to the depth of their market understanding (Park \& Kim, 2014; Santouridis \& Veraki, 2017). Furthermore, Akbari, M. et al. (2016) in their research paper, concluded that, the dimensions of relationship marketing including trust, commitment, communication, and conflict management led to greater customer loyalty, whereas customer loyalty had positive impact on word-of-mouth communication.

Palmatier and fellow researchers (2006) indicated that relationships are easier to build with individuals, as opposed to firms. That is, people like to have their individual and personal needs taken seriously. When firms are willing to explore those needs, and place a focus on defining those needs, this can facilitate creating positive connections, and relationships between the customer and the firm (Palmatier et al., 2006). As the authors explored in this writing, creating relationships with firms can also be helpful for companies, but it does not create the strong benefit that individual relationships can bring (Palmatier et al., 2006).

Tsao and Hsieh (2012) write that relationships play a role in helping to influence electronic word-of-mouth. Specifically, customers will help to spread a company's message if they have a feeling of commitment to the company. The findings suggested that just customer satisfaction and trust was not enough to produce an increase in word-of-mouth (Tsao \& Hsieh, 2012). Those factors needed 
to be converted into commitment in order for companies to see a positive benefit.

Research from Mullins, Ahearne, Lam, Hall and Boichuk (2014) highlighted that electronic word-of-mouth has been an important influence on the kind of relationships formed between online businesses and their customers. It has a significant effect on how customers perceive online s, brand image, and dimensions of functionality. Electronic word-of-mouth facilitates the formation of relations that lead to positive levels of trust, commitment, and satisfaction. Also, businesses do not have the capacity to form effective relations without optimizing communication through online platforms, which has become a business standard.

From the research conducted by Purnasari and Yuliando (2015), with the increased competition in the market, marketers are highly concerned with pleasing with customers. Their major focus is to retain customers rather than seeking for new ones by maintaining a long-term relationship (Purnasari \& Yuliando, 2015). Relationship quality is essential to the buyer's prediction of the future relationship with the salespeople of an organization. Being the major determinant of future interactions, its components include customer satisfaction, trust and commitment. Satisfaction has been defined as a situation where customers perceive that a product or service, which is delivered, is of high quality, or exceeds their expectations. Trust, on the other hand, refers to the confidence that customers develop due to the consistency, integrity and reliability of an organization (O'Reilly \& Marx, 2011). Commitment refers to the relationship between the customers and the organization, being the core point of relationship marketing.

This occurs only when the relationship is regarded beneficial. Customer commitment builds a positive attitude towards an organization, and it is often linked to customer satisfaction. Based on research, it is evident that consumer trust and satisfaction tends to increase commitment. Customer commitment and trust not only affect the real life word-of-mouth, but also drive them online and to spread e-WOM.

According to Purnasari and Yuliando (2015), it is evident that the relationship quality between customers and providers plays a key role in the customer's willingness to convey positive messages in online communities. Additionally, the quality of services offered by a firm has a direct impact on the customer's satisfaction, and an indirect impact on their trust. While they found that satisfaction and trust do not necessarily result in positive e-WOM communications from customers, positive e-WOM communication can only be achieved when satisfaction transforms into the commitment of the customer to the organization (Purnasari \& Yuliando, 2015). The research further emphasizes that satisfaction has a positive impact on trust; but trust does not lead to e-wom communication (Purnasari \& Yuliando, 2015). Trust is not automatically correlated to commitment or e-WOM. Regarding e-WOM communication today, factors such as customers' personal characteristics play a significant role. For instance, according to their research, the less a materialistic a customer is, the more likely they 
are to be satisfied and committed. Such individuals often share positive information regarding businesses that they have patronized, including sharing online. Purnasari and Yuliando, (2015) found that buyer's satisfaction is not reliable with their behavior patterns. Considering this, while building a good relationship with customers is important and ensuring, customer satisfaction is essential; maintaining customer commitment in today's competitive world is the key decisive factor.

From a research by Purnasari and Yuliando (2015), it is clear that relationship quality influences the way that buyers perceive their service providers, which in turn influences their future purchase behaviors. For this reason, relationship quality is beneficial, since it minimizes perceived risks linked to the integrity of a. With increasing relationship quality, online transactions will also increase provided consideration is being paid to the three dimensions, namely satisfaction, trust and commitment.

\subsection{Commitment, Trust, Satisfaction \& E-WOM}

Customer satisfaction, trust and commitment provided that the other constructs adequate to meet customer expectations is a basic requirement. The continued relationship cannot occur if the product or services do not match the customer's expectation of it. Satisfaction is a construct that contains customer evaluations of online s or products, which are collected from diverse interactions and transactions over a period of time. To reflect this, satisfaction can be defined as a cognitive and affective relationship formed after transactions.

Ismagilova, Dwivedi, Slade, and Williams (2017) discuss commitment as another product of effective promotion through electronic word-of-mouth. In current online transactions, commitment is an enduring desire to maintain the relationship between customers and those businesses that they purchase from another important construct shapes the direction of quality relationships. This occurs through the promotion of product information using electronic word-of-mouth. Commitment is a critical variable for measuring relationship quality, though its quality must be consistent alongside a willingness to make efforts toward sustaining an effective relationship.

Trust is an essential ingredient in creating a successful relationship to customers, particularly when making a transaction over the internet. Trust is the willingness to rely on another party in terms of expertise and ability to provide services without prior experience. Once trust has been developed, it creates a perception of confidence, dependability, reliability, and integrity (Trainor et al., 2014). Businesses should consider the trust of customers as their core goal to build long-term relationships, and electronic word-of-mouth will reflect that trust.

\subsection{Satisfaction and e-WOM}

Satisfaction is closely tied to e-WOM in that it is a major element of a long-term customer relationship (Yang, 2017). Satisfaction is defined as a situation where 
customers perceive that a service delivered is of high quality, or even exceeds their expectations.

It is a process of evaluation led by the consumer. Customers evaluate products and services based on their expectations. Satisfaction and a positive attitude towards the business can only be achieved if the perceived result meets the buyer's expectation, while dissatisfaction is the result achieved otherwise. The satisfaction and dissatisfaction of customers towards a good or service have a significant impact on $t$ future purchase behaviors.

H1: That customer satisfaction relates positively to positive e-WOM.

The positive behavioral intentions of customers are linked to positive e-WOM (Yang, 2017). If buyers develop a positive attitude towards a product or service, they will spread positive e-WOM. For this reason, the organization should focus on ensuring the satisfaction of the customer as without it positive e-WOM which improves and increases its profitability is not likely.

\subsection{Trust and e-WOM}

There is a direct relationship between trust and e-WOM, with satisfaction and commitment stemming from that trust. Fan, Miao, Fang and Lin (2013) recognize trust as one of the key factors that facilitate online buying. Online buying relies highly on the apparent risk perceived by the customer, and the degree of satisfaction. This risk can be minimized by trust enhancement. Trust is essential since it enables customers to deal with perceived risks, and be involved in trust-linked behaviors with the provider like sharing a personal experience.

H2: That customer trust relates positively to positive e-WOM.

Trust is the willingness to use other people's experiences in making an informed decision regarding a specific issue without any investigation. When there is trust, the reliance, reliability and belief in the integrity of the brand is enhanced significantly (Fan et al., 2013). Additionally, trust helps to minimize perceived fears and enhance online business since it decreases the customer's perception of fraud, doubts and possible risks (Fan et al., 2013). For these reasons, organizations should focus on creating long term relationships which will maximize the positive nature of the e-WOM.

Often, consumers react differently depending on the level of trust they have towards the e-WOM communication. In a situation where a buyer feels that there is some level of risk regarding e-WOM information, such as potential fake reviews. The customer is likely to try to find out more through additional queries to verify the information (Cheung \& Lee, 2012). On the other hand, if the perceived risk is low, their willingness to buy the goods or services will be higher.

\subsection{Commitment and e-WOM}

Commitment is tied to e-WOM given that products within the same category 
are not different, but are differentiated based on their branding (Noori et al., 2016). Brand commitment among customers offers an organization a competitive advantage within its industry.

H3: That customer commitment relates positively to positive e-WOM.

The research conducted by Noori and colleagues shows that commitment has a positive impact on a buyer's behavior. Through facilitating trust, an organization can develop a successful rapport in their marketing which in turn facilitates commitment. Commitment is therefore well supported by the e-WOM communications which are conveyed by customers through the internet-providing that it is positive. The author further emphasizes that commitment is the key steering factor of customer. From this research, it is evident that information communicated through e-WOM highly influences customer commitment and more so enhances his or her continuous consumption (Noori, Hashim, \& Yusof, 2016). In today's highly competitive internet marketing and the emergence of e-WOM, commitment plays a critical role in business success since it increases consumer purchasing habits and continuous use

\section{Research Methodology}

In this research, relationship quality, composed of customer commitment, trust and satisfaction, will be used as the independent variables. Customer positive electronic word-of-mouth is marked as a dependent variable. The conceptual model will use empirical methods, which allow descriptive features to be translated into quantifiable metrics that can be evaluated using descriptive statistics. In this study, a survey instrument was used, which, provides for the collection of primary data from a sample of the population of interest who were mobile phone users. This will allow for the identification of the nature of relations created though positive electronic word-of-mouth. Secondary research is used to explain the theoretical concepts and the proposed linkages between variables. Sampling techniques was employed to select the target sample of the study (Figure 1).

\subsection{Method of Data Collection}

This study required primary data collected from a sample of the population of interest. For this purpose, a survey questionnaire instrument was used. The

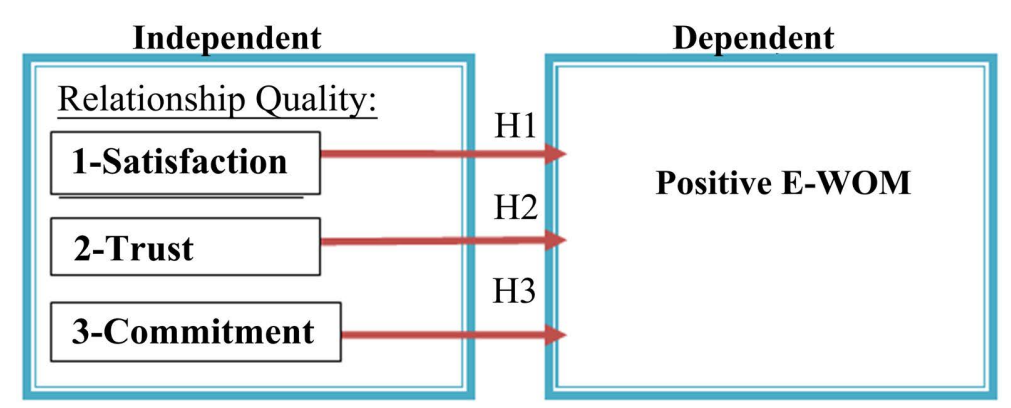

Figure 1. Research model. 
questionnaire instrument consisted of two parts. The first part consisted of questions on demographic and personal information. The demographic characteristics include gender, age, and education level. The second part was the core questions were each for creating an empirical data point related to each of the main variables of the study. This provided a structured method of conceptualizing the relationship between e-WOM, and relationship quality through the sub-measures of customer commitment, trust, and customer satisfaction (Table 1).

\subsection{Questionnaire Reliability}

The questionnaire method reliability was examined by using Cronbach's Alpha. The results in Table 2, show a Cronbach's Alpha value reaching 0.894, which guarantee a high reliability for the questionnaire instrument.

\subsection{Questionnaire Validity}

The questionnaire method validity measured by using Person's correlation coefficient to examine the degree of association between each item, and the total score of the dimension to which it related. The results presented as in Table 3,

Table 1. The study measurement for each factor and its references.

\begin{tabular}{|c|c|c|}
\hline Factors & Measurement OF EACH FACTOR & REFERENCES \\
\hline Satisfaction: & $\begin{array}{l}\text { 1) Delighted to have picked the product } \\
\text { 2) Have a favorable opinion of this product } \\
\text { 3) My shopping experiences at this virtual } \\
\text { store have always been pleasant } \\
\text { 4) Wish more products were like this one }\end{array}$ & $\begin{array}{c}\text { Tsao, W. C., \& } \\
\text { Hsieh, M. T. (2012). }\end{array}$ \\
\hline Trust & $\begin{array}{l}\text { 1) This product meets with my real needs } \\
\text { 2) The quality of this product is } \\
\text { 3) This product is honestly offered }\end{array}$ & $\begin{array}{c}\text { Tsao, W. C., \& } \\
\text { Hsieh, M. T. (2012). }\end{array}$ \\
\hline Commitment & $\begin{array}{l}\text { 1) I am willing to put a great deal of effort, by } \\
\text { beyond what is expected to help the success of } \\
\text { this brand } \\
\text { 2) I am proud to tell others that are a great brand } \\
\text { to be part of } \\
\text { 3) It will take very little to cause me to leave this } \\
\text { brand }\end{array}$ & $\begin{array}{l}\text { Jafari, Karimi, } \\
\text { Forouzandeh, \& } \\
\text { Safahani (2015). }\end{array}$ \\
\hline E-WOM & $\begin{array}{l}\text { 1) I am willing to let other Internet users } \\
\text { know that I am a customer of this } \\
\text { product/company } \\
\text { 2) I am willing to provide more positive } \\
\text { online information about this product } \\
\text { available to other Internet users } \\
\text { 3) I am willing to positively discuss this } \\
\text { product with other people on the Internet } \\
\text { 4) I am willing to share positive information } \\
\text { about this product with others on the internet }\end{array}$ & $\begin{array}{c}\text { Tsao, W. C., \& } \\
\text { Hsieh, M. T. (2012). }\end{array}$ \\
\hline
\end{tabular}


Table 2. Survey questionnaire reliability.

\begin{tabular}{ccc}
\hline Dimensions & No. of items & Cronbach's alpha \\
\hline Customer satisfaction & 4 & 0.835 \\
Trust & 4 & 0.773 \\
Commitment & 4 & 0.679 \\
e-WOM & 4 & 0.897 \\
Overall reliability & 16 & 0.894 \\
\hline
\end{tabular}

Table 3. Survey questionnaire validity.

\begin{tabular}{cccccccc}
\hline $\begin{array}{c}\text { Dimension one: } \\
\text { Customer satisfaction }\end{array}$ & \multicolumn{2}{c}{$\begin{array}{c}\text { Dimension two: } \\
\text { Customer trust }\end{array}$} & $\begin{array}{c}\text { Dimension three: } \\
\text { Commitment }\end{array}$ & \multicolumn{2}{c}{$\begin{array}{c}\text { Dimension four: } \\
\text { e-WOM }\end{array}$} \\
\hline $\begin{array}{c}\text { Item } \\
\text { No. }\end{array}$ & $\begin{array}{c}\text { Correlation } \\
\text { coefficient }\end{array}$ & $\begin{array}{c}\text { Item } \\
\text { No. }\end{array}$ & $\begin{array}{c}\text { Correlation } \\
\text { coefficient }\end{array}$ & $\begin{array}{c}\text { Item } \\
\text { No. }\end{array}$ & $\begin{array}{c}\text { Correlation } \\
\text { coefficient }\end{array}$ & $\begin{array}{c}\text { Item } \\
\text { No. }\end{array}$ & $\begin{array}{c}\text { Correlation } \\
\text { coefficient }\end{array}$ \\
\hline 1 & $0.887^{* *}$ & 5 & $0.764^{* *}$ & 9 & $0.770^{* *}$ & 13 & $0.783^{* *}$ \\
2 & $0.810^{* *}$ & 6 & $0.790^{* *}$ & 10 & $0.853^{* *}$ & 14 & $0.903^{* *}$ \\
3 & $0.860^{* *}$ & 7 & $0.736^{* *}$ & 11 & $0.739^{* *}$ & 15 & $0.907^{* *}$ \\
4 & $0.730^{* *}$ & 8 & $0.806^{* *}$ & 12 & $0.500^{* *}$ & 16 & $0.911^{* *}$ \\
\hline
\end{tabular}

${ }^{*}$ indicated that correlation coefficient is statistically significant at the $(0.01)$ significant level.

reveal that, all the questionnaire items significantly correlated with the dimension to which is related, meaning all items achieved the purpose of measurement.

\section{Results}

This section is in concern with data analysis, in particularly testing the researchunderlined hypotheses, which aim to examine the correlation relationship between the dependent and independent variables conceptualized in the research model. To do that, correlation and multiple regression analysis conducted. In addition to that, participants of the study described according to gender, age, and education level. The results illustrated as in Table 4.

Table 4, reveal that, in regard to participant distribution according to gender, the female comprised the majority by $79.1 \%$ while the male just represents $20.9 \%$. Indicating that, the females have the highest participation in the current study. While participants' distribution according to age show the majority $64.6 \%$ at the age level 19 - 30 years, while $20.2 \%$ at the age category 31 - 40 years, while under 18 comprised $9 \%$ with few percent for above 40 years. Whereas the distribution of participants according to educational level, show that, almost participants obtain bachelor degree $57.1 \%$, higher school and below $23.7 \%$, master $18 \%$, and $\mathrm{PhD}$ holders represents the lowest $>1.2 \%$. 
Table 4. Participants demographic characteristics.

\begin{tabular}{ccc}
\hline Gender & Frequency & Percent \% \\
Male & 84 & 20.9 \\
Female & 317 & 79.1 \\
\hline Age by years & 36 & 9.0 \\
\hline Under 18 & 259 & 64.6 \\
19 to 30 & 81 & 20.2 \\
31 to 40 & 25 & 6.2 \\
Above 40 & & \\
\hline Highest education level & 95 & 23.7 \\
Higher school and below & 229 & 57.1 \\
Bachelor & 72 & 18.0 \\
Master & 5 & 1.2 \\
\hline PhD or other & & \\
\hline
\end{tabular}

\subsection{Research Hypotheses}

To verify the research hypotheses, two statistical techniques used to do that, Person's Correlation coefficient and multiple regression analysis were conducted, as will be illustrated in the following tables.

\subsubsection{Results of Research Hypothesis One: That Customer Satisfaction Relates Positively to Positive e-WOM}

Table 5 reveals that, the value of correlation coefficient between the customer satisfaction, and e-WOM, is reaching (0.370) and statistically significant at the $(0.01)$ level. This indicates that, there is a significant positive correlation relationship between customer satisfaction and e-WOM. Meaning that, whenever customers were satisfied they provide positive ideas, attitudes towards the product or service they consume. Therefore, they will provide positive e-WOM, which influence on other customers purchase decision.

\subsubsection{Results of Testing Hypothesis Two: Customer Trust Relates Positively to Positive e-WOM}

Table 6, showed that, the value of correlation coefficient between the customer trust, and e-WOM, is reaching (0.437) which is statistically significant at the (0.01) level. Meaning that, there is a significant and positive correlation relationship between customer trust and e-WOM. This result indicates that, if companies work to fulfill their customers' trust that will make customers to say good and positive words in favor of their companies' product and service through social media sites. Thus, companies can get more benefits as their customer's size will increase due to positive electronic word of mouth.

\subsubsection{Results of Testing Hypothesis Three: Stated That Customer Commitment Relates Positively to Positive e-WOM}

The results in Table 7, showed that, the value of correlation coefficient between 
Table 5. Relationship between customer satisfaction, and e-WOM.

\begin{tabular}{ccc}
\hline \multicolumn{2}{c}{ e-WOM } \\
\hline Variables & Correlation coefficient & $P$-value \\
& 0.370 & $0.00^{* *}$ \\
\hline
\end{tabular}

${ }^{*}$ indicated that correlation coefficient is significant at the $(0.01)$ level.

Table 6. Correlation relationship between customer trust and e-WOM.

\begin{tabular}{ccc}
\hline Variables & \multicolumn{2}{c}{ e-WOM } \\
\hline & correlation coefficient & $P$-value \\
Customer trust & 0.437 & $0.00^{\star *}$ \\
\hline
\end{tabular}

**indicated that correlation coefficient is significant at the (0.01) level.

Table 7. Correlation relationship between customer commitment and e-WOM.

\begin{tabular}{ccc}
\hline Variables & \multicolumn{2}{c}{ e-WOM } \\
\hline \multirow{2}{*}{ Customer commitment } & correlation coefficient & $P$-value \\
& 0.548 & $0.00^{* *}$ \\
\hline
\end{tabular}

**indicated that correlation coefficient is significant at the (0.01) level.

customer commitment, and e-WOM, is reaching (0.548) which is statistically significant at the (0.01) level. The result confirmed that, when companies committed to serve their customers with the required products or services, customers would contribute positively towards their company's brands.

\subsection{Multiple Regression Analysis}

The aim of multiple regression analysis is to examine how relationship quality factors as independent factors influence on Electronic Word of Mouth (EWOM) as a dependent variable. The research apply the multiple regression analysis equation as written:

$$
\mathrm{EWOM}=b+b_{1} s+b_{2} T+b_{3} C
$$

where, $b$ stand for constant, $b_{1}, b_{2}, b_{3}$ stand for coefficient, and $S$, $T$, and $C$ denoted the independent factors satisfaction, trust, and commitment.

\subsection{The Results Illustrated in Table 8}

Table 8 shows that, the value of F-statistics is equal to (67.844) is statistically significant at the (0.01) level, indicating that the multiple regression model is effective to estimate the change in the electronic word of mouth. In addition to that, the coefficient of determination $\left(\mathrm{R}^{2}\right)$ reaching $(0.345)$ indicates that, the relationship quality factors including (satisfaction, trust, and commitment) explains around $35 \%$ of the changes in EWOM, approximately if other factors remain equal.

The results in Table 8 also reveal that, there is statistically positive correlation 
Table 8. Results of regression analysis.

\begin{tabular}{ccccccc}
\hline & $\begin{array}{c}\text { Coefficients } \\
(\mathrm{B})\end{array}$ & Beta & $\begin{array}{c}\text { T-test } \\
\text { statistics }\end{array}$ & $P$-value & F-statistics & $P$-value \\
\hline Constant & 0.213 & & 0.683 & 0.50 & & \\
Satisfaction & 0.196 & 0.123 & 2.315 & $0.02^{\star}$ & & \\
Trust & 0.216 & 0.144 & 2.533 & $0.012^{*}$ & & \\
Commitment & 0.501 & 0.431 & 9.05 & $0.00^{* *}$ & & \\
$\mathrm{R}=0.587$ & $\mathrm{R}^{2}=0.345$ & \multicolumn{2}{c}{ Adj. $\mathrm{R}^{2}$} & Durbin-Watson $=1.811$ \\
\hline
\end{tabular}

relationship between each of the relationship quality factors and the EWOM. Meaning that, the relationship quality factors influence positive on customers, which make them to provide positive EWOM when reviewing the company's website, which in turn influencing and encourage other users to take a positive purchase decision in favor of the company products or services.

\section{Discussion}

The purpose of the current study is to explain how the relationship quality between consumers and mobile phone companies can influence positive electronic word of mouth through the customer. It is necessary to bring the discuss information back to the hypotheses set forth within the context of the study.

The Current study concluded with various findings. Therefore, this section of the research paper concentrate to discuss the major findings of the study. Among these findings is that, customers have a very high level of satisfaction towards their mobile's phone brands, therefore consumers delighted to have picked their mobile's brand, and they appreciated their experiences while shopping at the virtual mobile shopping store. Therefore, the results support that, there is statistically significant and positive relationship between customer satisfaction and e-WOM. Meaning that satisfaction of customers generates a positive influence on e-WOM. Such an e-WOM, through the interaction of mobile's phone users influences other people on the internet to purchase the same product. The findings is supported by many other researchers, Kimmel \& Kitchen (2014), stated that, The exchange of information between consumers has a considerable impact on the consumer's behavior, in addition to that, the Electronic word-of-mouth (e-WOM) plays a crucial role in consumer spending decisions. On the same way, Chu and Choi (2011), argued that, the electronic word-of-mouth refers to any positive or negative information made by customers regarding a product or an organization in various online platforms. This sharing of information among consumers has had considerable impact on consumer purchasing behavior, and it has transferred the convincing power from marketers to the consumers.

With regard to customers trust of their mobile's phone brands who search the companies review site, the results confirmed that most customers have a high level of trust of their mobile's phone companies, therefore, mobile's brand is 
highly effective in meeting the customer daily needs, and the mobile's brand fully satisfies customers' expectations. Hence, the research concludes that, there is a significant and positive correlation relationship between customer trust and e-WOM. Thus, whenever customers trusted their companies' brands they will provide positive e-WOM, which increased other customer's trust, which in turn will have an effect on other brands' buyers, because consumers believe each other. Therefore, these results matched with the conclusions provided by various researchers such as (Yoo, Kim, \& Sanders, 2015; Noori, Hashim, \& Yusof, 2016) who believed that, e-WOM has proven to be an important foundation of ensuring that customers have high levels of confidence, satisfaction. So, it is possible today to find consumers to trust each other, and share their experience in the marketing place on online platforms.

Furthermore, one of the interesting findings of the current study is that customers have positive attitudes to be committed to their mobile's phones brands. The most important evidences supporting that, customers perceived that their mobile's brand is the best brand of all possible brands to be part of, and most customers were proud to tell other people that their mobile's brand is a great to be part of. Therefore, it is logical; the result proved that, there is a significant and positive association between customer's commitment to their mobile phone brands, and the Electronic Word of Mouth (e-WOM). Hence, the influence of eWOM, on customers' commitment was supported and argued in literature by many contributors in the area of the study. Mullins [w1], Ahearne, Lam, Hall and Boichuk (2014) confirmed that electronic word-of-mouth has been an important influence on the kind of relationships formed between online businesses and their customers; in addition to that, it facilitates the formation of relations that lead to positive levels of trust, commitment, and satisfaction.

\section{Recommendations}

The study be recreated using a more evenly disbursed population, as opposed to almost $80 \%$ female to slightly more than $20 \%$ male. The majority of participants were within the target consumers range from the purchase of such devices, it is believed that there is a possibility that a more equitable gender distribution may result in a greater understanding of the consumer population. In light of the positive perspectives associated with the electronic word of mouth of products, and the influence of the same on the decision of the individual to select a particular mobile phone or mobile phone provider, it is recommended that these statistics be provided by the mobile phone companies in Saudi Arabia, it may be possible for a mobile phone company within the area to increase its overall market share by capitalizing on an effective online word of mouth campaign.

It is further recommended that, in light of the effect of electronic word of mouth on consumer purchasing decisions, that the mobile phone providers in the region review their online presence in order to identify potential areas of detriment within that online presence that could decrease the probability of a con- 
sumer purchase decision in the company's favor, and further steps be taken to identify and resolve any consumer identified issues in real time, decreasing the likelihood of a negative impact on the organization in regards to any future issues arise.

\section{Implication \& Conclusion}

The purpose of this paper was to explore critical components of the relationship of quality as it pertains to marketing and business in order to answer the identified research question, specifically, "how does the relationship quality can influence consumer commitment, trust, and satisfaction based on the positive electronic word of mouth. The researcher hoped to determine the role that quality played in consumer selection of electronics, and the relationship between the business offering the electronic product and the marketing of that product, based on word of mouth electronic discussions.

Analysis of the results of the study showed that customer satisfaction related positively to positive electronic word of mouth from other consumers. Furthermore, it also reveals that consumer trust related positively to electronic word of mouth and that consumer commitment to the brand and positively associated with positive electronic word of mouth. As a result, the research question can be answered by stating that electronic word of mouth discussions made by prior mobile phone consumers play a significant role in the decision of the consumer when selecting a new product. It is opinions of others regarding the mobile phone that the individual is considering play the largest role in the decision of the individual to acquire a new phone, the majority of participants are both satisfied with the purchase decision and are increasingly likely to remain loyal to the brand.

Thus, each consumer has a strong idea of the type of phone brand that desires and has created a method of obtaining additional resources to guarantee the next phone to be purchased based on that information. This implies additional consumer research, mobile phone brands could provide better offerings to their customer needs, and further increasing the likelihood of acquisition following release and leaving the companies with the potential to obtain a greater market share. While there is still much additional research to be done with regard to the actions and decisions made by consumers regarding their mobile phone acquisition in Saudi Arabia, the completion of this research study has provided a solid foundation from which to base additional research. The identification of the effects of electronic word of mouth is a strong start in the identification of additional actions that may be taken in order to increase the influence of a mobile phone company on the purchase made by consumers.

\section{Imitation of the Study}

There were a number of limitations faced this study. One of the most crucial limitation of this research is the sample size that was related to the nature of the 
study. The study use the convenient sampling for selecting sample, which cannot consider as truly representative of the population. So, the researcher only able to solicit information from 401 customers of mobile review sites of businesses in the Saudi market. Therefore, the study findings may not have a great chance for generalizability. In addition to that, time constrain is another limitation of the study.

\section{Future Scope}

Future researchers have the chance to expand the same issue of the study to include more participants on the level of Saudi Arabia mobile market. The future researchers can add more variables in concern to customers such as customers' loyalty to examine how electronic word of mouth influence on customers satisfaction, loyalty, trust, and commitment to their brands of mobile phones. More studies needed in Saudi market, as there is an active market for consuming mobile phones.

\section{Conflicts of Interest}

The author declares no conflicts of interests.

\section{References}

Akbari, M., Kazemi, R., \& Haddadi, M. (2016). Relationship Marketing and Word-of-Mouth Communications: Examining the Mediating Role of Customer Loyalty. Marketing and Branding Research, 3, 63-74. https://doi.org/10.33844/mbr.2016.60193

Andreassen, T. W., \& Streukens, S. (2009). Service Innovation and Electronic Word-of-Mouth: Is It Worth Listening to? Managing Service Quality: An International Journal, 19, 249-265. https://doi.org/10.1108/09604520910955294

Bhat, N. Y., \& Bhat, S. A. (2020). The Influence of Electronic Word of Mouth (eWOM) on Consumers Purchase Intentions: A Review and Analysis of the Existing Literature. IOSR Journal of Engineering (IOSRJE), 10, 27-36.

Bilgihan, A., \& Bujisic, M. (2015). The Effect of Website Features in Online Relationship Marketing: A Case of Online Hotel Booking. Electronic Commerce Research and Applications, 14, 222-232. https://doi.org/10.1016/j.elerap.2014.09.001

Bolton, P., Bass, J., \& Neugebauer, R. (2003). Group Interpersonal Psychotherapy for Depression in Rural Uganda: A Randomized Controlled Trial. JAMA, 289, 3117-3124. https://doi.org/10.1001/jama.289.23.3117

Cheung, C. M. K., \& Lee, M. K. O. (2012). What Drives Consumers to Spread Electronic Word of Mouth in Online Consumer-Opinion Platforms. Decision Support Systems, 53, 218-225. https://doi.org/10.1016/j.dss.2012.01.015

Chu, S. C., \& Choi, S. M. (2011). Electronic Word-of-Mouth in Social Networking Sites: A Cross-Cultural Study of the United States and China. Journal of Global Marketing, 24, 263-281. https://doi.org/10.1080/08911762.2011.592461

Clow, K. E., \& Baack, D. (2009). Marketing Management: A Customer-Oriented Approach. Sage Publications.

Crosby, L. A., Evans, K. R., \& Cowles, D. (1990). Relationship Quality in Services Selling: An Interpersonal Influence Perspective. Journal of Marketing, 54, 68-81. 
https://doi.org/10.1177/002224299005400306

Datta, H., Foubert, B., \& Van Heerde, H. J. (2015). The Challenge of Retaining Customers Acquired with Free Trials. Journal of Marketing Research, 52, 217-234. https://doi.org/10.1509/jmr.12.0160

Dick, A. S., \& Basu, K. (1994). Customer Loyalty: Toward an Integrated Conceptual Framework. Journal of the Academy of Marketing Science, 22, 99-113. https://doi.org/10.1177/0092070394222001

Fan, Y. W., Miao, Y. F., Fang, Y. H., \& Lin, R.Y. (2013). Establishing the Adoption of Electronic Word-of-Mouth through Consumers' Perceived Credibility. International Business Research, 6, 58-65. https://doi.org/10.5539/ibr.v6n3p58

Farooqi, S. R. (2014). The Construct of Relationship Quality. Journal of Relationships Research, 5, Article e2. https://doi.org/10.1017/jrr.2014.2

Forrester, W. R., \& Maute, M. F. (2001). The Impact of Relationship Satisfaction on Attributions, Emotions, and Behaviors Following Service Failure. Journal of Applied Business Research, 17, 1-14. https://doi.org/10.19030/jabr.v17i1.8148

Frischmann, T., \& Gensler, S. (2011). Influence of Perceptual Metrics on Customer Profitability: The Mediating Effect of Behavioral Metrics. Journal of Financial Services Marketing, 16, 14-26. https://doi.org/10.1057/fsm.2011.4

Guede, J. R. S., Curiel, J. E., \& Antonovica, A. (2017). Word-of-Mouth Communication as a Consequence of Relationship Quality in Online Environments. Palabra Clave, 21, 1075-1106. https://doi.org/10.5294/pacla.2018.21.4.6

Haytko, D. L. (2004). Firm-to-Firm and Interpersonal Relationships: Perspectives from Advertising Agency Account Managers. Journal of the Academy of Marketing Science, 32, 312-328. https://doi.org/10.1177/0092070304264989

Hechanova, G., \& Cementina-Olpoc, R. (2013). Transformational Leadership, Change Management, and Commitment to Change: A Comparison of Academic and Business Organizations. The Asia-Pacific Education Researcher, 22, 11-19.

https://doi.org/10.1007/s40299-012-0019-z

Ismagilova, E., Dwivedi, Y. K., Slade, E., et al. (2017). Electronic Word of Mouth (eWOM) in the Marketing Context: A State of the Art Analysis and Future Directions. New York City: Springer International Publishing. https://doi.org/10.1007/978-3-319-52459-7

Jafari, S. M. B., Karimi, A., Forouzandeh, M., \& Safahani, N. (2015). The Effect of Brand Commitment on e-WOM and Brand Image in the Mobile Market. Research Journal of Applied Sciences, 10, 519-524.

Johanesova, V., \& Vanova, J. (2020). What Is Relationship Marketing and How to Use It to Connect with Your Customers. Research Papers Faculty of Materials Science and Technology Slovak University of Technology, 28, 29-35. https://doi.org/10.2478/rput-2020-0004

Kang, B., Oh, S., \& Sivadas, E. (2013). Beyond Relationship Quality: Examining Relationship Management Effectiveness. Journal of Marketing Theory and Practice, 21, 273-288. https://doi.org/10.2753/MTP1069-6679210303

Kannan, P. K., \& Li, H. (A.) (2017). Digital Marketing: A Framework, Review and Research Agenda. International Journal of Research in Marketing, 34, 22-45. https://doi.org/10.1016/j.ijresmar.2016.11.006

Katz, E., Lazarsfeld, P. F., \& Roper, E. (2017). Personal Influence: The Part Played by People in the Flow of Mass Communications. Routledge. https://doi.org/10.4324/9781315126234 
Khan, C. M. U. H. (2016). Saudi Arabia's Vision 2030. Defence Journal, 19, 36-42.

Khoshsima, S., Kiani, A., Safari, A., Amari, S., Shifte, M., \&Vaseei, M. (2013). The Impact of Brand Credibility on Customer Loyalty. International Journal of Business and Behavioral Sciences, 3, 24-34.

Kimmel, A. J., \& Kitchen, P. J. (2014). WOM and Social Media: Presaging Future Directions for Research and Practice. Journal of Marketing Communications, 20, 5-20. https://doi.org/10.1080/13527266.2013.797730

King, R. A., Racherla, P., \& Bush, V. D. (2014). What We Know and Don't Know about Online Word-of-Mouth: A Review and Synthesis of the Literature. Journal of Interactive Marketing, 28, 167-183. https://doi.org/10.1016/j.intmar.2014.02.001

Miquel-Romero, M. J., Caplliure-Giner, E. M., \&Adame-Sánchez, C. (2014). Relationship Marketing Management: Its Importance in Private Label Extension. Journal of Business Research, 67, 667-672. https://doi.org/10.1016/j.jbusres.2013.11.025

Mullins, R. R., Ahearne, M., Lam, S. K., Hall, Z. R., \& Boichuk, J. P. (2014). Know Your Customer: How Salesperson Perceptions of Customer Relationship Quality Form and Influence Account Profitability. American Marketing Association. https://doi.org/10.1509/jm.13.0300

Myhal, G. C., Kang, J., \& Murphy, J. A. (2008). Retaining Customers through Relationship Quality: A Services Business Marketing Case. Journal of Services Marketing, 22, 445-453. https://doi.org/10.1108/08876040810901864

Niraj, R., Foster, G., Gupta, M. R., \& Narasimhan, C. (2008). Understanding Customer Level Profitability Implications of Satisfaction Programs. Journal of Business \& Industrial Marketing, 23, 454-463. https://doi.org/10.1108/08858620810901211

Noori, A. S., Hashim, K. F., \&Yusof, S. A. M. (2016). The Conceptual Relation of Electronic Word-of-Mouth, Commitment and Trust in Influencing Continuous Usage of Social Commerce. International Review of Management and Marketing, 6, 226-230.

O’Reilly, K., \& Marx, S. (2011). How Young, Technical Consumers Assess Online WOM Credibility. Qualitative Market Research, 14, 330-359. https://doi.org/10.1108/13522751111163191

Palmatier, R. W., Dant, R. P., Grewal, D., \& Evans, K. R. (2006). Factors Influencing the Effectiveness of Relationship Marketing: A Meta-Analysis. Journal of Marketing, 70, 136-153. https://doi.org/10.1509/jmkg.70.4.136

Park, H., \& Kim, Y. K. (2014). The Role of Social Network Websites in the Consumer-Brand Relationship. Journal of Retailing and Consumer Services, 21, 460-467. https://doi.org/10.1016/j.jretconser.2014.03.011

Parsons, A. L. (2002). What Determines Buyer-Seller Relationship Quality? An Investigation from the Buyer's Perspective. Journal of Supply Chain Management, 38, 4-12. https://doi.org/10.1111/j.1745-493X.2002.tb00124.x

Poomduang, T., \& , Kheokao, J. (2019). Dimensions of Relationship Quality: The Sense of Strength between Consumer and Brand. International Conference on Social Sciences in the 21st Century, Amsterdam, 12-14 July 2019. https://doi.org/10.33422/ics21.2019.07.384

Purnasari, H., \& Yuliando, H. (2015). How Relationship Quality on Customer Commitment Influences Positive e-WOM. Agriculture and Agricultural Science Procedia, 3, 149-153. https://doi.org/10.1016/j.aaspro.2015.01.029

Rawson, A., Duncan, E., \& Jones, C. (2013). The Truth about Customer Experience. Harvard Business Review, 91, 90-98.

Santouridis, I., \& Veraki, A. (2017). Customer Relationship Management and Customer 
Satisfaction: The Mediating Role of Relationship Quality. Total Quality Management \& Business Excellence, 28, 1122-1133. https://doi.org/10.1080/14783363.2017.1303889

Shankara, A., Jebarajakirthyb, C., \& Ashaduzzamanb, M. (2020). How Do Electronic Word of Mouth Practices Contribute to Mobile Banking Adoption? Journal of Retailing and Consumer Services, 52, Article ID: 101920.

https://doi.org/10.1016/j.jretconser.2019.101920

Sheth, S., \& Kim, J. (2017). Social Media Marketing: The Effect of Information Sharing, Entertainment, Emotional Connection and Peer Pressure on the Attitude and Purchase Intentions. GSTF Journal on Business Review (GBR), 5.

Trainor, K. J., Andzulis, J. M., Rapp, A., \& Agnihotri, R. (2014). Social Media Technology Usage and Customer Relationship Performance: A Capabilities-Based Examination of Social CRM. Journal of Business Research, 67, 1201-1208.

https://doi.org/10.1016/j.jbusres.2013.05.002

Tsao, W. C., \& Hsieh, M. T. (2012). Exploring How Relationship Quality Influences Positive eWOM: The Importance of Customer Commitment. Total Quality Management \& Business Excellence, 23, 821-835. https://doi.org/10.1080/14783363.2012.661137

Yang, F. X. (2017). Effects of Restaurant Satisfaction and Knowledge Sharing Motivation on eWOM Intentions: The Moderating Role of Technology Acceptance Factors. Journal of Hospitality \& Tourism Research, 41, 93-127.

https://doi.org/10.1177/1096348013515918

Yoo, C. W., Kim, Y. J., \& Sanders, G. L. (2015). The Impact of Interactivity of Electronic Word-of-Mouth Systems and E-Quality on Decision Support in the Context of the e-Marketplace. Information \& Management, 52, 496-505. https://doi.org/10.1016/j.im.2015.03.001

Zargari, K., \&Hazraty, M. (2016). Considering Effect of Quality of Communication and Customer Commitment on Word-of-Mouth Advertisement of Customers of Melli Bank in Rasht City. The Turkish Online Journal of Design Art and Communication, 6, 688-697. https://doi.org/10.7456/1060JSE/037

Zhu, F., \& Zhang, X. (2010). Impact of Online Consumer Reviews on Sales: The Moderating Role of Product and Consumer Characteristics. Journal of Marketing, 74, 133-148. https://doi.org/10.1509/jm.74.2.133 